\title{
THE IMPACT OF BILINGUALISM AND AGING ON INHIBITORY CONTROL AND WORKING MEMORY
}

\author{
Johanna Dagort Billig ${ }^{1}$ \\ Ana Paula Scholl ${ }^{2}$
}

Resumo: Evidências de uma vantagem bilíngue em algumas funções executivas sugerem que o bilinguismo poderia atenuar o declínio destas habilidades cognitivas ao longo do envelhecimento. O presente estudo buscou investigar a influência do bilinguismo no desempenho de idosos (60-71 anos) e adultos (40-55 anos) em tarefas envolvendo dois componentes das funções executivas: controle inibitório e memória de trabalho. Os resultados encontrados revelam um efeito de idade em termos de controle inibitório e memória de trabalho, mas não um efeito de experiência de linguagem. Entretanto, os participantes bilingues foram ligeiramente mais rápidos que os monolíngües em todas as condições das tarefas de controle inibitório.

Palavras-chave: bilinguismo, envelhecimento, funções executivas, memória de trabalho

\section{INTRODUCTION}

A considerable number of studies have investigated the effects of early bilingualism beyond the language domain. Several pieces of

\footnotetext{
1 Doutoranda do Programa de Linguística Aplicada da UFRGS, professora da Universidade Federal do Rio Grande (FURG)

2 Universidade Federal do Rio Grande do Sul (UFRGS)

Organon, Porto Alegre, nํ51, julho-dezembro, 2011, p. 39-52
} 
evidence from these studies suggest a bilingual advantage in terms of executive control across the lifespan (BIALYSTOK, CODD, 1997; BIALYSTOK, MARTIN, 2004; BIALYSTOK et al. 2004; CARLSON, MELTZOF, 2008; COSTA, HERNANDEZ, SEBASTIÁN-GALLÉS, 2008). The hypothesis is that the need to control attention to two or more active language systems results in constant practice of attentional control for bilinguals/multilinguals, which would lead to enhanced levels of executive control in nonverbal tasks.

According to Diamond (2006), executive control is a set of cognitive skills that includes: inhibitory control (ability to inhibit attention to irrelevant information), working memory (ability to hold information and manipulate it) and cognitive flexibility (ability to switch perspective, focus of attention, or response mappings). Diamond (2006) states that this set of cognitive skills is required to deal with novel tasks and situations involving the following demands: concentration, planning, problem solving, coordination, change, conscious choices among alternatives, or overriding a strong internal or external pull.

Executive control is known to follow an inverted U-shaped trajectory across the lifespan, with children and older adults showing poorer performance and being more influenced by external pull than young adults. The aging decline of executive control is worrying if we consider the growing number of older adults in the world population. In Brazil, for instance, according to IBGE (2008), $62.4 \%$ of the elderly adults are responsible for their domiciles. Therefore, poorer performances in terms of executive control can pose a serious threat to this population.

According to Greenwood and Parasuraman (2010), after focusing on age-related cognitive decline for a long time, researchers now seem to show more interest in investigating environmental factors and behaviors that can ameliorate the course of cognitive and brain aging and mitigate the effects of illnesses that produce dementia, for instance. Higher levels of education, stimulating leisure and social activities have been related to decreased rates of cognitive decline (SCARMEAS, STERN, 2003; VALENZUELA, SACHDEV, 2006; STAFF et al., 2004). Recent studies have also related bilingualism to decreased rates of cognitive decline (BIALYSTOK, CRAIK, FREEDMAN, 2007; KAVE et al., 2008; CRAIK, BIALYSTOK, FREEDMAN, 2010). 
Studies investigating the impact of lifelong bilingualism on older adults have reported the following findings: a bilingual advantage in terms of inhibitory control (BIALYSTOK et al., 2004; BIALYSTOK, CRAIK, RYAN, 2006); a better performance of bilinguals in a task involving higher demands of working memory (BIALYSTOK et al., 2004); an advantage in terms of inhibitory control limited to balanced bilinguals (ZIED et al., 2004); a bilingual advantage in planning (CRAIK, BIALYSTOK, 2006); a poorer performance of bilinguals in a task of verbal memory (FERNANDES et al., 2007); evidence of bilingualism as a form of cognitive reserve (BIALYSTOK, CRAIK, FREEDMAN, 2007; KAVÉ et al., 2008; CRAIK, BIALYSTOK, FREEDMAN, 2010); evidence of a bilingual advantage in the recollection component of memory retrieval (WODNIECKA et al., 2010) and in the emotional version of the Cahill test ( MARTINS, 2009).

Despite the aging of the world population and the accumulated evidence that cognitive decline can be modulated by environment factors, most of the studies found (Medline, Pubmed, PsyINFO, Portal de Periódicos Capes) on bilingualism were carried out with children or young adults. Therefore, studies addressing the possibility of bilinguals' enhanced levels of executive control throughout aging are important and necessary.

In order to contribute to this body of research, the present study attempted to investigate the effects of bilingualism and aging on inhibitory control and working memory. Two versions of the Simon Task and one version of the Stroop Test were used to assess the performance of older adults (60-71 years) as well as of younger adults ( $40-55$ years). Our question was whether the bilingual advantage in these two components of the executive control extended to a different population of adults. On the basis of previous results we expected to find a bilingual advantage in terms of inhibitory control and working memory.

\section{MET HOD}

\section{Participants}

Eighty-three healthy participants were assigned to four groups according to their age (older/younger) and language experience (bilingual/monolingual). The older participants were between the ages of 60 and 71. According to the World Health Organization (IBGE, 2000), in Organon, Porto Alegre, nº 51, julho-dezembro, 2011, p. 39-52 
developing countries, you are considered an older citizen at the age of 60. The younger ones were between the ages of 40 and 55. The older bilingual group (OB) and the younger bilingual group (YB) were composed respectively of twenty-one and twenty early Hunsrückisch/ Brazilian Portuguese bilinguals. Twenty-one Brazilian Portuguese monolinguals composed the older monolingual group (OM) and twenty-one the younger group (YM). Monolinguals reported not being fluent in any other language. Bilinguals had learned Hunsrückisch at home and Brazilian Portuguese at school at the age of 7 , and used both languages continuously ever since. All participants were recruited from Santa Cruz do Sul and Arroio do Tigre, which are, respectively, a city and a small town in the south of Brazil. All of them attended school for no more than eight years and had no previous computer experience. Most of them were employed as maids, small farmers, bricklayers and machine operators. Only one bilingual and one monolingual participant were left-handed. All participants had normal or corrected-to-normal vision. Each participant gave informed consent.

\section{Tasks}

Language and health background questionnaire

This questionnaire included questions on language acquisition and frequency and context of language use. It also collected information about medical history, and alcohol and drug history.

Mini Mental State Examination (MMSE)

This is a widely used 30-point questionnaire to screen for cognitive impairment. It provides measures of orientation to time and place, registration (immediate memory), attention and calculation, shortterm memory, basic motor skills, as well as language functioning. Participants' scores were interpreted to account for their level of education (Bertolucci et al., 1994).

\section{Geriatric Depression Scale (GDS)}

This is a screening test for depressive symptoms in the elderly (YESAVAGE et al., 1983). The 30-item questionnaire may be answered yes or no. A score of 10 or 11 is the usual threshold to separate depressed from nondepressed patients. Participants who screened positive for depression were left out of the sample.

Organon, Porto Alegre, no 51 , julho-dezembro, 2011, p. 39-52 
Simon Arrows Task

In order to measure inhibitory control, a modified version of Simon and Rudell's (1967) task based on stimulus-response compatibility effects was used. Directional arrows were used as the stimuli and were presented on a 14-in. color monitor from an ACER laptop running E-Prime 1.2. Each trial began with a fixation cross (+) in the center of the screen, which remained visible for $800 \mathrm{~ms}$ and was followed by a $250-\mathrm{ms}$ blank interval. At the end of this interval, a red arrow appeared on the screen. Participants responded by pressing the "1" key (on the left) when they saw an arrow pointing to the left and the " 0 " key (on the right) when they saw an arrow pointing to the right. These keys were labeled with stickers to avoid confusion and prevent participants from pressing the wrong keys. A set of eight practice trials preceded the control (24 trials) and the lateral (24 trials) conditions. Participants had to complete all eight trials successfully to proceed to the experimental trials for each condition. In the control condition, the red arrow appeared in the middle of the screen. Within the lateral trials, half were congruent and half were incongruent. The incongruent trials were supposed to make higher demands in terms of inhibitory control.

\section{Simon Squares Task}

The experiment was presented on the same laptop computer used for the Simon Arrows Task. Each trial began with a fixation cross (+) in the center of the screen, which remained visible for $800 \mathrm{~ms}$ and was followed by a 250 -ms sound file "ding." The stimulus appeared immediately after the ding. In this version of the Simon Task, there were four different types of stimuli (a blue square, a yellow square, a green square and an orange square), which appeared in the center of the screen. This condition would supposedly place greater demands on working memory, in terms of maintenance of information in an active state. There was no need for the participant to manipulate information; therefore, this was a maintenance only task. There were 48 experimental trials. Participants were instructed to press the " 1 " key when they saw a blue square, the " 0 " key when they saw a green square, the " 1 " key when they saw a yellow square, and the "0" key when they saw an orange square. A set of eight practice trials preceded the task.

Organon, Porto Alegre, ํำ51, julho-dezembro, 2011, p. 39-52 
Stroop Test

Inhibitory control was also assessed by means of an adaptation of the Stroop color-naming test (STROOP, 1935). The stimuli were the color names "pink" and "green" written in Portuguese (rosa, verde), printed in capital letters in 100-point Arial font, presented in the middle of the screen. Participants were instructed to press " 1 " when they saw a word in pink color font and to press " 0 " when they saw a word in green color font. Each trial began with a fixation cross (+) presented for $300 \mathrm{~ms}$, followed by a 250 -ms sound file "ding." The stimulus appeared immediately after the ding. There were 12 congruent trials in which the word and font color corresponded and 12 incongruent trials in which the word and font color did not correspond. The incongruent trials were supposed to require a higher demand of inhibitory control. Before the experiment, a training phase of eight trials was administered.

\section{Procedure}

Firstly, participants were contacted by phone in order to arrange an initial screening interview. This contact was made by one member of their own community in order to make them feel more comfortable to receive the researchers. No more than ten people refused to receive the researchers in their homes. After answering questions about their language exposure and use as well as their health state, the older participants took MMSE and GDS. These were followed by the test session. The order of the tasks was counterbalanced across participants. The interview and the tests were all conducted in the participants' homes by the same experimenters on the same equipment. Participants were tested individually and they typically completed all tasks within $1 \mathrm{hr}$. An informed consent was obtained from all participants.

\section{RESULTS}

Categorical variables were described in terms of their absolute frequency. The Chi-square test was used to compare the categorical variables. Mean and standard deviation were used to describe the quantitative variables with symmetric distribution and compared among them using One-way ANOVA and the multiple comparisons by the

Tukey test. When normality was not found, the data were compared by Kruskall-Wallis tests and Mann-Whitney tests.

Organon, Porto Alegre, n⿳0 51, julho-dezembro, 2011, p. 39-52 


\section{Background variables}

A hundred and three people were interviewed. Nobody was excluded from the sample due to their scores in the GDS or MMSE. However, two people were excluded due to use of fluoxetine (antidepressant); one person due to alcoholism; three people due to previous cancer history and one person due to epilepsy history. Furthermore, eleven of the interviewed people were excluded from our sample because they had more than eight years of formal education. Mean scores and standard deviations for the background measures are reported in Table 1. Older participants were not different in age, male/female ratio, schooling or MMSE scores. Younger participants were also equivalent in age and representation of males and females. However, there was a significant difference in terms of schooling among the younger participants, with monolinguals having a higher schooling.

TABLE 1: Mean Background Measures

\begin{tabular}{lcccc}
\hline & \multicolumn{2}{c}{ Younger $(n=41)$} & \multicolumn{2}{c}{ Older $(n=42)$} \\
\cline { 2 - 5 } & Monolingual & Bilingual & Monolingual & Bilingual \\
Measure & $(n=21)$ & $(n=20)$ & $(n=21)$ & $(n=21)$ \\
\hline Age & $48.3 \pm 4.2$ & $49.8 \pm 3.5$ & $65.2 \pm 3.1$ & $65.30 \pm 3.2$ \\
Female Sex (\%) & $13(61.9)$ & $13(65)$ & $13(61.9)$ & $13(61.9)$ \\
Schooling (in years) & $6.6 \pm 1.5^{\star}$ & $5.0 \pm 1.2^{*}$ & $4.8 \pm 2.1$ & $4.2 \pm 0,4$ \\
MMSE & $\mathrm{x}$ & $\mathrm{x}$ & $27.0 \pm 3.6$ & $27.2 \pm 2.1$ \\
\hline Note. $n=$ number of participants; * ${ }^{*}$ statistically significant & &
\end{tabular}

\section{Simon Arrows Task}

The mean reaction times (RTs) and mean accuracy scores by age and language group for the control, congruent and incongruent trials are shown in Table 2. The results for the control condition showed no effect of language. Younger bilinguals and monolinguals were comparable in terms of response time and accuracy as well as older bilinguals and monolinguals. Nonetheless, the older adults were slower $(p=0.001)$ and less accurate $(p=0.023)$ than the younger participants.

Regarding the congruent condition, there were no significant differences between language groups in response time. Nevertheless, younger monolinguals were more accurate than younger bilinguals $(p=0.024)$. An effect of age was again found in terms of response time and accuracy. Younger participants were faster $(p=0.006)$ and scored higher $(p=0.038)$.

Organon, Porto Alegre, n 51, julho-dezembro, 2011, p. 39-52 
The main effect of language group did not yield statistical significance for the incongruent trials. However, older participants were slower $(p=0.015)$. As anticipated, congruent trials were performed more rapidly $(p=0.001)$ and more accurate $(p=0.001)$ than incongruent trials by all groups.

The RT difference between congruent and incongruent stimuli (the Simon effect) reflects the efficiency of inhibitory processes. The mean Simon effect was $92.9 \mathrm{~ms}(S D=188.1 \mathrm{~ms})$ for young monolinguals, $19.5 \mathrm{~ms}(S D=187.8 \mathrm{~ms})$ for young bilinguals, $100.3(S D=176.4 \mathrm{~ms})$ for older monolinguals, and $57.8(S D=167.5)$ for older bilinguals. Despite large differences in these values (Simon Effect), there was no significant effect of language.

\begin{tabular}{|c|c|c|c|c|c|c|c|}
\hline \multirow[b]{2}{*}{ ge and language group } & \multirow[b]{2}{*}{ Control (ms) } & \multirow[b]{2}{*}{$\begin{array}{c}\text { Accuracy } \\
\text { (\%) }\end{array}$} & \multicolumn{4}{|c|}{ Lateral } & \multirow[b]{2}{*}{$\begin{array}{c}\text { Simon } \\
\text { Effect(ms) }\end{array}$} \\
\hline & & & $\begin{array}{c}\text { Congruent } \\
\text { (ms) }\end{array}$ & $\begin{array}{c}\text { Accuracy } \\
(\%)\end{array}$ & $\begin{array}{c}\text { Incongruent } \\
\text { (ms) }\end{array}$ & $\begin{array}{c}\text { Accuracy } \\
(\%)\end{array}$ & \\
\hline \multicolumn{8}{|l|}{$(n=41)$} \\
\hline Monolingual ( $n=21)$ & $624.6 \pm 253.9$ & 93.3 & $851.3 \pm 338.4$ & 90.8 & $944.2 \pm 451.3$ & 84.5 & $92.9 \pm 188.1$ \\
\hline Bilingual $(n=20)$ & $569 \pm 175.4$ & 99.5 & $831 \pm 259.5$ & 86.6 & $850.3 \pm 212.9$ & 78.3 & $19.5 \pm 187.8$ \\
\hline \multicolumn{8}{|l|}{$=42)$} \\
\hline Monolingual ( $n=21)$ & $881.4 \pm 477$ & 94.1 & $1075 \pm 694.3$ & 95.0 & $1175.9 \pm 639.5$ & 84.5 & $100.3 \pm 176.4$ \\
\hline Bilingual $(n=21)$ & $749.8 \pm 401$ & 95.8 & $1000.4 \pm 407.8$ & 86.6 & $1058.2 \pm 375.6$ & 84.5 & $57.8 \pm 167.5$ \\
\hline
\end{tabular}

\section{Simon Squares Task}

Accuracy scores and RTs in the Simon Squares Task as a function of age and language group are presented in Table 3. There was no effect of language, but there was a negative effect of age. There was a speed $(p=0.02)$ and an accuracy $(p=0.006)$ advantage to the younger adults.

TABLE 3: Simon Squares Task

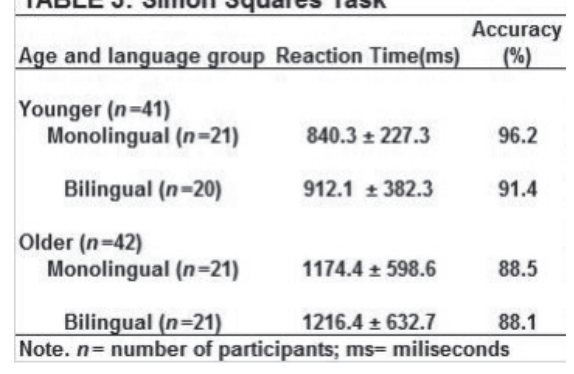

Organon, Porto Alegre, nº 51, julho-dezembro, 2011, p. 39-52 


\section{Stroop Test}

Performance on the Stroop Test is reported in Table 4. Response time to congruent trials showed no difference between language groups or age groups. However, younger monolinguals $(p=0.023)$ were more accurate than younger bilinguals.

The scores of the incongruent trials showed no difference between language groups or age groups. Consistent with expectations, the results revealed an effect of congruency. Larger costs of time were associated with incongruent trials $(p=0.019)$.

The Stroop effect is the RT difference between congruent and incongruent trials. As in the Simon Arrows Task, the magnitude of the difference (Stroop Effect) was the same for monolinguals and bilinguals as well as for younger and older participants.

TABLE 4: Stroop Task

\begin{tabular}{|c|c|c|c|c|c|}
\hline Age and Language Group & $\begin{array}{c}\text { Congruent } \\
\text { (ms) }\end{array}$ & $\begin{array}{c}\text { Accuracy } \\
(\%)\end{array}$ & $\begin{array}{c}\text { Incongruent } \\
\text { (ms) }\end{array}$ & $\begin{array}{c}\text { Accuracy } \\
(\%)\end{array}$ & $\begin{array}{c}\text { Stroop Effect } \\
\text { (ms) }\end{array}$ \\
\hline \multicolumn{6}{|l|}{ Younger $(n=41)$} \\
\hline Monolingual ( $n=21)$ & $693.8 \pm 269.1$ & 99.1 & $740.3 \pm 247.2$ & 96.6 & $46.6 \pm 191.7$ \\
\hline Bilingual $(n=20)$ & $632.4 \pm 203.9$ & 95.8 & $660.8 \pm 184$ & 92.5 & $28.3 \pm 215.9$ \\
\hline \multicolumn{6}{|l|}{ Older $(n=42)$} \\
\hline Monolingual $(n=21)$ & $814.2 \pm 369.9$ & 98.3 & $858 \pm 458.2$ & 95.8 & $43.7 \pm 168.7$ \\
\hline Bilingual $(n=21)$ & $721.6 \pm 319.6$ & 95.0 & $784.7 \pm 329.1$ & 94.1 & $63.0 \pm 117.6$ \\
\hline
\end{tabular}

Note. $n=$ number of narticinants: $\mathrm{ms}=$ miliseconds

\section{DISCUSSION}

The purpose of the present study was to explore the bilingual and aging effects on inhibitory control and working memory. To do so, we assessed inhibitory control by means of a version of the Simon Task and a version of the Stroop Test, and working memory by means of another version of the Simon Task.

As expected, our results showed an age-related decrement. In the Simon Arrows Task, older participants were slower in congruent and incongruent trials. They were also less accurate in congruent trials. In 
the Simon Squares Task, older participants performed less well than their younger counterparts. Similar effects have been reported previously (BIALYSTOK et al., 2004), therefore, our results may be taken as confirmation that our participants were representative of their respective age groups.

On the other hand, there were no significant age differences in the Stroop Test. This may be attributed to the fact that our sample had received no more than eight years of formal education. That is, low-schooling can be associated with low reading time and, therefore, the linguistic stimuli could not have worked as an effective source of conflict as expected.

Regarding the language experience effect, we failed to observe a bilingual advantage. Given the results from previous studies (BIALYSTOK et al.2004, 2006), we expected that bilingualism would be associated with smaller conflict effects and smaller costs of working memory (BIALYSTOK et al., 2004). Bilinguals and monolinguals performed similarly in the working memory task. This results are at odds with those from Bialystok and collaborators (2004), but consistent with the results from Bialystok and collaborators (2008). The latter study reported a similar performance of monolinguals and bilinguals in two types of working memory tasks (Corsi blocks and Self-ordered pointing).

With regard to inhibitory control, the conflict produced by incongruent trials was not significantly smaller for bilinguals. Bilinguals and monolinguals did not differ from each other, but there was a slight trend for the bilinguals to be faster in incongruent trials as well as in congruent trials, especially among older adults. This pattern of result was also reported by previous studies (SALVATIERRA, 2007; COSTA et al., 2008; PINTO, 2009). Costa and collaborators (2009) believe that this speed advantage also present in congruent trials may be an evidence of efficiency of the conflict monitoring system.

As pointed out by Costa and collaborators (2009), a growing body of research has used two types of evidence as an index of a bilingual advantage: a smaller conflict effect for bilinguals and an overall speed advantage for bilinguals in conflict resolution tasks. According to them, smaller conflict effects can be a sign of processes recruited in suppressing interference, but a speed advantage that spreads even to congruent trials may be a sign of a bilingual advantage in the efficiency of the conflict monitoring system. In order to explore the conditions that lead to a bilingual advantage, the researchers manipulated the involve- 
ment of the monitoring system by the percentage of congruent and incongruent trials in an ANT task. They hypothesized that monitoring demands were supposed to be higher in the tasks in which trials were more evenly distributed. The results showed that bilinguals had a better performance in tasks involving higher demands on the monitoring system, but had a similar performance to monolinguals on the tasks involving lower demands.

In our tasks, the congruent and incongruent trials were evenly distributed (50/50), that is, the involvement of the monitoring system was high. Therefore, the slight trend for the bilinguals to be faster even in the presence of congruent stimuli can be interpreted as an enhanced ability to monitor attention.

The lack of a significant effect of language experience can be attributable to a false negative, since we only had twenty participants in each group. Another way of considering the discrepancies in results between our study and previous studies (BIALYSTOK et al., 2004; COSTA, HERNANDEZ, SEBASTIÁN-GALLÉS, 2008) is to attribute the bilingual advantage to interactions between bilingualism and other variables, such as type of bilingualism, participants' age and educational level. Our sample differed considerably from most of the samples of previous studies. Our participants did not receive formal education on Hunsrückisch, they could only read and write in Portuguese. They had up to eight years of formal education and none or almost none experience with computers. Besides that, the age of our older participants ranged from 60 to 71. In developing countries, you are considered in older citizen at the age of 65 . According to Salvatierra (2007), the analyses by decades done by Bialystok and collaborators (2004) suggest that a bilingual advantage may be not apparent until the seventh decade of life. Therefore, the trend of a bilingual advantage in the performance of the Simon Arrows Task may become more pronounced as years pass.

In conclusion, our data suggest that aging leads to a decline in the efficiency of inhibitory control and working memory. With regard to language experience, we believe that further studies are still necessary to investigate the exact components of executive control that are influenced by a bilingual language experience. Besides that, we believe that future work should also focus on the interaction of bilingualism with other variables. Not only bilingualism, but also other environmental factors may influence the executive control throughout the lifespan.

Organon, Porto Alegre, ํำ51, julho-dezembro, 2011, p. 39-52 


\section{REFERENCES}

BERTOLUCCI, P. et al. O mini-exame do estado mental em uma população geral: impacto da escolaridade. Arq Neuropsiquiatr., v. 52, p. 1-7, 1994.

BIALYSTOK, E.; CODD, J. Cardinal limits: evidence from language awareness and bilingualism for developing concepts of number. Cognitive Development, v. 12, p. 85-106,1997.

BIALYSTOK, E.; MARTIN, M. M. Attention and inhibition in bilingual children: evidence from the dimensional change card sort task. Developmental Science, v. 7, p.325-339, 2004.

BIALYSTOK, E. et al. Bilingualism, aging, and cognitive control: Evidence from the Simon task. Psychology and aging, v. 19, p. 290-303, 2004.

BIALYSTOK, E.; CRAIK, F. I.; RYAN, J. Executive control in a modified anti-saccade task: Effects of aging and bilingualism. Journal of Experimental Psychology: Learning, Memory, and Cognition, v. 32, p. 1341-1354, 2006.

BIALYSTOK, E.; CRAIK, F. I.; FREEDMAN, M. Bilingualism as a protection against the onset of symptoms of dementia. Neuropsychologia, v. 45, p. 459-464, 2007.

BIALYSTOK, E.; CRAIK, F. I.; LUK, G. Cognitive control and lexical access in younger and older bilinguals. Journal of Experimental Psychology: Learning, Memory, and Cognition, v. 34, n. 4, p. 859-873, 2008. CARLSON, S.; MELTZOFF, A. Bilingual experience and executive functioning in young children. Developmental Science, v. 11, n. 2, p. 282-298, 2008.

COSTA, A.; HERNANDEZ, M.; SEBASTIÁN-GALLÉS, N. Bilingualism aids conflict resolution: evidence from the ANT task. Cognition, v. 106, p. 59-86, 2008.

COSTA, A. et al. On the bilingual advantage in conflict processing: now you see it, now you don't. Cognition, n.113, p. 135-149, 2009. CRAIK, F. I.; BIALYSTOK, E. Planning and task management in older adults: cooking breakfast. Memory \& Cognition, v. 34, n. 6, p. 12361249, 2006.

CRAIK, F.; BIALYSTOK, E.; FREEDMAN, M. Delaying the onset of Alzheimer disease: bilingualism as a form of cognitive reserve. Neurology, v. 75, p. 1726-1729, 2010.

Organon, Porto Alegre, nº 51, julho-dezembro, 2011, p. 39-52 
DIAMOND, A. The early development of executive functions. In:

BIALYSTOK, E.; CRAIK, F. I. M. (eds.) Lifespan cognition: mechanisms of change. Nova Iorque: Oxford, 2006.

FERNANDES, M. et al. Effects of bilingualism, aging, and semantic relatedness on memory under divided attention. Canadian Journal of Experimental Psychology, v. 61, n. 2, p. 128-141, 2007.

GREENWOOD, P.; PARASURAMAN, R. Neuronal and cognitive plasticity: a neurocognitive framework for ameliorating cognitive aging. Frontiers in aging neuroscience, v. 2, p. 1-14, 2010.

INSTITUTO BRASILEIRO DE GEOGRAFIA E ESTATÍSTICA. Projeção da população do Brasil por sexo e idade 1980-2050 (Revisão 2008). Rio de Janeiro: IBGE, 2008. Disponível em: <http://www.ibge. gov.br/home/estatistica/populacao/projecao_da_populacao/2008/ default.shtm>. Acesso em: 13 nov. 2009.

KAVÉ, G. et al. Multilingualism and cognitive state in the oldest old. Psychology and Aging, v. 23, n. 1, p. 70-78, 2008.

MARTINS, S. A. Diferenças entre idosos bilíngues e monolíngües no desempenho de tarefas relacionadas às funções executivas, memória de trabalho e memória emocional de longo prazo. Pelotas, 2009.

Dissertação (Mestrado em Let ras)- Universidade Católica de Pelotas. PINTO, L. M. A relação entre o bilingüismo e as funções executivas no envelhecimento. Porto Alegre, 2009. Dissertação (Mestrado em Let ras)- Centro Universitário Ritter dos Reis.

SALVATIERRA, J. L. The effect of bilingualism and aging on inhibitory control. Flórida, 2007. Tese (Doutorado em Filosofia) - Charles Schmidt College of Science, Florida Atlantic University.

SCARMEAS, N.; STERN, Y. Cognitive reserve and lifestyle. Journal of Clinical and Experimental Neuropsychology, v. 25, p.625-633, 2003.

SIMON, J. R.; ALLAN, P. R. Auditory S-R compatibility: The effect of an irrelevant cue on information processing. Journal of Applied Psychology, v. 51, 300-304, 1967.

STAFF, R. T. et al. What provides cerebral reserve? Brain, v. 127, p. 1191-1199, 2004.

STROOP, J. Ridley. Studies of inference in serial verbal reactions. Journal of Experimental Psychology, v. 18, 643-662, 1935.

VALENZUELA, M. J.; SACHDEV, P. Brain reserve and cognitive decline: a non-paramet ric systematic review. Psychological Medicine, v. 36, p. 1065-1073, 2006.

Organon, Porto Alegre, n 51, julho-dezembro, 2011, p. 39-52 
WODNIECKA, Z. et al. Does bilingualism help memory? Compet ing effects of verbal ability and executive control. International Journal of Bilingual Education and Bilingualism, v. 13, n. 5, 2010.

YESAVAGE, J.A. et al. Development and validation of a geriatric depression screening scale: a preliminary report. J. Psychiatr Res, v. 17, p. 37-42,1983.

ZIED, K. M. et al. Bilingualism and adult differences in inhibitory mechanisms: evidence from a bilingual stroop task. Brain and Cognition, v. 54, p.254-256, 2004. 